Available online at website :

http://e-journal.adpgmiindonesia.com/index.php/jmie

JMIE: Journal of Madrasah Ibtidaiyah Education, 5(2), 2021, 277-294

\title{
IMPLEMENTASI PROGRAM PENDIDIKAN YANG DIINDIVIDUALKAN (PPI) DI SD INKLUSIF DI WILAYAH JAKARTA SELATAN
}

\author{
Siti Masyithoh \\ Fakultas Ilmu Tarbiyah dan Keguruan UIN Syarif Hidayatullah Jakarta \\ siti.masyithoh@,uinjkt.ac.id
}

Submit: 13 Maret 2021, Revisi: 22 Oktober 2021, Approve: 8 November 2021

\begin{abstract}
This study aims to describe the implementation of the Individualized Education Program in Inclusive Elementary Schools in South Jakarta. The research method used is a descriptive qualitative research that is casuistic in nature at SDN 01 Lebak Bulus and SDN 02 Lebak Bulus in South Jakarta. The subjects in this study were principals, teachers and students with special needs. In this study, the researcher used several instruments, namely document studies, interviews and observations that were used in various ways which were also used to measure the level of validity of the data through the triangulation process. The samples of this study were teachers, principals, and students in 2 (two) inclusive elementary schools in South Jakarta, namely SDN 01 Lebak Bulus and SDN 02 Lebak Bulus. The results showed that the recruitment of Special Advisor Teachers from graduates of Special Education had been carried out at SDN 01 and 02 Lebak Bulus, South Jakarta. However, the 95\% Individual Education Program could not be implemented in these schools due to the absence of a legal protection that protects the rights of Special Guiding Teachers so that they cannot provide proper academic services to students with special needs. Teachers who were originally recruited to become Special Guidance Teachers were turned into classroom teachers in regular classes. As a result, students with special needs cannot be served properly and their learning achievement becomes retarded. Self-development and self-development for these students also cannot be carried out because of the clash of funds and human resources.Keywords: Children with Special Needs, Individual Education Programs
\end{abstract}

Keywords: Implementasi, Anak Dengan kebutuhan Khusus, Program Pendidikan Individual.

Pengutipan: Siti Masyithoh. (2021). Implementasi Program Pendidikan yang Diindividualkan (PPI) di SD Inklusif di Wilayah Jakarta Selatan. JMIE: Journal of Madrasah Ibtidaiyah Education, 5(2), 2021, 277-294. jmie.v5i2.362.

Permalink/DOI: http:/ /dx.doi.org/10.32934/jmie.v5i2.362 


\section{PENDAHULUAN}

Pemenuhan hak mengenyam pendidikan merupakan hak semua anak tidak terkecuali bagi anak dengan kebutuhan khusus (ABK). Persamaan hak dalam pendidikan dan pengajaran bagi anak dengan kebutuhan khusus memang menjadi sebuah keniscayaan sesuai Undang-undang Dasar 1945 pasal 31 di mana setiap warga negara berhak memperoleh pengajaran dan pendidikan yang sama. Anak berkebutuhan khusus merupakan bagian dari warga negara yang menjadi sasaran pendidikan nasional yang bertujuan untuk mengembangkan kemampuan serta meningkatkan mutu kehidupan dan martabat manusia Indonesia seutuhnya. Hal itu diterjemahkan dalam Undang-undang Sistem Pendidikan Nasional No. 20 tahun 2003 yang menyatakan bahwa pendidikan bertujuan mencerdaskan kehidupan bangsa dan mengembangkan manusia Indonesia seutuhnya, yaitu manusia yang beriman dan bertaqwa terhadap Tuhan Yang Maha Esa dan berbudi pekerti luhur memiliki pengetahuan dan keterampilan, kesehatan jasmani dan rohani, kepribadian yang mantap dan mandiri serta rasa tanggung jawab kemasyarakatan dan kebangsaan. Berdasarkan hal itu maka negara memiliki tanggung jawab dan berkewajiban untuk memberikan pelayanan pendidikan yang bermutu kepada setiap warganya tanpa terkecuali termasuk anak-anak yang memiliki keberbadaan dengan anak-anak lainnya.

Convention on the Rights of Person with Disabilities and Optional Protocol yang disahkan pada Maret 2007, disebutkan dalam pasal 24 bahwa salah satu kesepakatan Internasional yang dibuatnya adalah mendorong terwujudnya sistem pendidikan inklusif secara global. Dalam konvensi ini disebutkan bahwa setiap negara berkewajiban dan bertanggung jawab dalam penyelenggaraan sistem pendidikan inklusif. Salah satu tujuan terpentingnya adalah untuk mendorong terwujudnya partisipasi penuh anak berkebutuhan khusus dalam kehidupan bermasyarakat. Hal ini dapat terwujud melalui pendidikan, sebab kebutuhan mendasar setiap manusia agar keberlangsungan hidupnya terjamin dan bermartabat adalah pendidikan. Di Indonesia, negara telah berupaya merealisasikan pendidikan inklusif melalui PERMENDIKNAS No. 70 Tahun 2009 tentang pendidikan inklusif bagi peserta didik. Kemudian pada PP No. 170 Tahun 2010 pasal (1) dijelaskan bahwa pendidikan inklusif dapat dilaksanakan di semua jenjang dan jenis pendidikan dari tingkat pendidikan dasar hingga menengah. Hal ini sebagai upaya pemerintah dalam rangka mengakomodir keberagaman, sehingga tidak memunculkan segmentasi lembaga pendidikan yang berdasarkan pada perbedaan kemampuan baik fisik maupun mental yang terdapat dalam diri setiap siswa sebagaimana yang terjadi sebelumnya. Karena segmentasi lembaga pendidikan yang ada selama ini telah menghambat para siswa untuk belajar dmenghormati an menghormati realitas keberagaman yang terdapat dalam masyarakat. Sebelumnya, anak-anak yang memiliki perbedaan kemampuan dan kekhususan (difabel), disediakan fasilitas dan jalur pendidikan khusus yang disesuaikan dengan jenis dan derajat perbedaannya yang disebut dengan Sekolah Luar Biasa (SLB). Sistem pendidikan SLB telah membangun tembok eksklusifisme bagi anak-anak 
dengan kebutuhan khusus. Tembok eksklusifisme tersebut tanpa disadari telah menghambat proses sosialisasi untuk saling mengenal dan berinteraksi antara anak-anak difabel dengan anakanak normal lainnya. Akibatnya, dalam proses sosialisasi masyarakat, kelompok anak-anak dengan kebutuhan khusus ini menjadi komunitas yang terasingkan dari dinamika dan kehidupan sosial di masyarakat. Selanjutnya masyarakat juga menjadi merasa asing dan tidak akrab dengan kehidupan kelompok anak-anak berkebutuhan khusus tersebut. Sementara itu kelompok anak-anak berkebutuhan khusus sendiri juga merasa bahwa keberadaannya bukan menjadi bagian dari kehidupan masyarakat di sekitarnya, sehingga dalam proses selanjutnya mereka kesulitan dalam beradaptasi dan berkontribusi di tengah-tengah masyarakat.

Para pakar Pendidikan sering mendengungkan slogan sekolah untuk semua dan telah mendapatkan dukungan dalam usaha mengakomodir anak dengan kebutuhan khusus agar dapat bersekolah dengan anak-anak normal tanpa ada sekat dan batasan. Sistem pendidikan yang mencampurkan anak berkebutuhan khusus dengan anak normal disebut dengan sistem pendidikan inklusif yang seharusnya menerapkan kurikulum adaptif. Hal ini juga yang menandakan bahwa pendidikan tersebut menganut sistem berkeadilan sosial yang berprinsip pada keseimbangan dan pemerataan hak serta kewajiban bagi setiap warga negara. Pemerataan tersebut berlaku untuk semua warga negara, termasuk bagi mereka yang memiliki hambatan belajar atau dengan kebutuhan khusus.

Pendidikan Inklusif adalah kebersamaan untuk memperoleh pelayanan pendidikan dalam satu kelompok secara utuh bagi seluruh anak dengan kebutuhan khusus di usia sekolah, agar anak dengan kebutuhan khusus dapat bersosialisasi dan bersama-sama dengan anak sebayanya yang normal di sekolah reguler, juga merupakan solusi terhadap kendala sulitnya anak dengan kebutuhan khusus untuk mendapatkan pelayanan pendidikan secara utuh terutama di desa dan daerah terpencil. Maka anak reguler perlu disiapkan untuk dapat belajar, kesiapan guru, media atau sarana prasarana, lingkungan, dan yang tidak kalah penting untuk disiapkan adalah proses pembelajaran itu sendiri, yakni pembelajaran yang sesuai dengan kurikulum yang telah ditetapkan sebagai pedoman pembelajaran demi tercapainya tujuan pendidikan dan juga sesuai dengan kebutuhan peserta didik. Setiap sekolah pasti mempunyai kurikulum yang merupakan pedoman penyelenggaraan kegiatan pembelajaran, dan perlu disusun agar memungkinkan pengembangan keragaman minat, potensi, emosional, kecerdasan intelektual, spiritual, serta karakteristik peserta didik secara optimal sesuai dengan tingkat kemampuan dan perkembangan peserta didik. Berkaitan dengan itu sekolah harus tetap mengembangkan kurikulum yang mengacu kepada standar nasional dan diarahkan dalam rangka mewujudkan tujuan pendidikan nasional.

Di era otonomi daerah atau otonomi dalam bidang pendidikan sekarang ini, tiap sekolah memiliki hak dalam mengembangkan kurikulum yang sesuai dengan sumber daya alam, tujuan pendidikan daerah dan karakteristik daerah setempat yang dituangkan dalam 
program pengajaran, materi pelajaran, metode maupun evaluasi pembelajaran. Kurikulum yang digunakan di sekolah penyelenggara pendidikan inklusif harus bersifat fleksibel sesuai dengan kemampuan atau kebutuhan peserta didik (Hidayat, 2009: 39). Kurikulum harus fleksibel dan tidak kaku. Artinya, bahwa kurikulum itu harus bisa dilaksanakan sesuai dengan kebutuhan dan kondisi yang ada. Kondisi kurikulum yang kaku atau tidak fleksibel akan sulit diterapkan dalam proses pelaksanaan sistem pendidikan yang bersifat inklusif. Fleksibilitas kurikulum adalah program pembelajarannya bersifat lentur yang dikembangkan dalam suatu Program Pembelajaran Individual (Individualized Education Program/IEP). Program pembelajaran individual merupakan suatu kurikulum terindividualisasi yang didasarkan kepada kebutuhan khusus anak dalam belajar, karena dalam sekolah dengan pendekatan pendidikan inklusif tersebut, terdapat anak dengan kebutuhan yang memiliki karakteristik, kebutuhan dan kemampuan yang berbeda. Disamping itu perlu juga diperhatikan bagaimana proses pembelajaran yang diindividualkan dapat terlaksana dengan baik tanpa harus merusak keberadaan kurikulum yang ada, dengan menselaraskan kesenjangan antara kondisi yang ada dengan kondisi yang diharapkan Undang-undang No 20, tentang Sistem Pendidikan Nasional, Tahun 2003. Convention on the Rights of Person with Disabilities and Optional Protocol,http:/ / www.un.org/disabilities/default.asp\%3Fid\%3D150 (diakses pada 6 Maret 2017).

Dari pemaparan di atas, dapat dijelaskan bahwa seharusnya tidak ada sekolah inklusif tanpa adanya pelayanan Program Pendidikan Individual bagi ABK. Artinya, PPI merupakan bagian yang tidak terpisahkan dari realisasi penyelanggaraan Pendidikan inklusif yang menjadi kebijakan pemerintah saat ini. Sementara, Beberapa orangtua yang memiliki anak berkebutuhan khusus lmenjelaskan bahwa mereka lebih memilih menyekolahkan anaknya tetap di SLB dengan dalih bahwa PPI di sekolah inklusif tidak terlaksana sebagaimana yang seharusnya.

Dalam wawancara terhadap beberapa orangtua dengan anak berkebutuhan khusus, mereka menjelaskan bahwa anak-anak mereka yang disekolahkan di sekolah reguler tidak mendapatkkan pelayanan pendidikan sesuai kebutuhan anak-anaknya di sekolah tempat mereka belajar. Hal ini melatarbelakangi peneliti untuk menggali secara lebih mendalam tentang bagaimana implementasi PPI (Program Pendidikan Individual) pada SD/MI inklusi di DKI Jakarta.

\section{TINJAUAN PUSTAKA DAN LITERATURE REVIEW}

\section{Definisi PPI (Program Pendidikan Individual)}

Perbedaan yang terdapat pada setiap individu merupakan salah satu hal yang terpenting yang harus diperhatikan dalam merancang program pembelajaran terutama pembelajaran bagi anak dengan kebutuhan khusus. Munculnya sekolah inklusi yang membaurkan anak dengan kebutuhan khusus dan anak-anak normal dengan tujuan tertentu, mengharuskan pendidik untuk merancang suatu program pembelajaran yang bertujuan melayani 
secara khusus kebutuhan masing-masing anak yang berbeda. Program tersebut dikenal dengan Program Pendidikan Invidual. Mercer menjelaskan bahwa PPI merupakan dokumen tertulis yang dikembangkan dalam suatu rencana pembelajaran bagi ABK (ATG) ... suatu program dimana siswa bekerja dengan tugas-tugas yang sesuai dengan kondisi dan motivasinya (Mercer \& Mercer, 1989:5). Program Pembelajaran Individual, ini berisi rumusan program pembelajaran yang dikembangkan menjadi suatu program yang berdasarkan hasil assessment terhadap kemampuan individu anak (Assjari, 2005:38). Dalam bukunya Suparno dkk (2007: 27) menjelaskan bahwa PPI memuat: identitas siswa secara jelas, lengkap dengan masalah dan kemampuan yang dikuasai, serta dilengkapi dengan komponen rancangan pembelajaran, yaitu: materi, kegiatan dan penilaian.

Suatu PPI pada umumnya dibuat dan dikembangkan oleh guru PLB (guru pembimbing khusus) yang bertugas di sekolah reguler. Guru pembimbing khusus menyusun dan mengembangkan PPI untuk memastikans bahwa setiap anak berkebutuhan khusus dapat memperoleh program Pendidikan yang diindividualkan dalam rangka memberikan akomodasi layak yang sesuai dengan kebutuhan-kebutuhan khas yang dimiliki mereka, dan mengomunikasikan program tersebut kepada orang-orang yang berkepentingan dalam bentuk program yang tertulis. Hal ini diharapkan dapat membantu para guru untuk mengadaptasikan program umum dan/ khusus bagi anak berkesulitan belajar yang bertolak dari kekuatan, kelemahan, dan minat anak.

The United State Code menjelaskan sebagaimana dikutip Kitano dan Kirby (1986: 158), hendaknya PPI memuat lima hal: (1) taraf kemampuan yang dimiliki anak saat ini, (2) penentuan tujuan umum yang hendak dicapai dalam waktu tertentu dan menjabarkannya kedalam tujuantujuan pembelajaran yang lebih khusus, (3) menyediakan pelayanan khusus bagi anak dan perluasannya untuk mengikuti program reguler, (4) penentuan kapan dimulainya kegiatan dan berapa waktu yang digunakan untuk memberikan pelayanan, dan (5) prosedur penilaian dan penetapan kriteria keberhasilan atau kegagalan program.

\section{Pengertian Anak Dengan kebutuhan Khusus dalam Setting Inklusif}

Anak dengan kebutuhan khusus adalah anak yang memiliki kebutuhan khusus dan perbedaan dengan anak- anak normal seusianya. Anak dapat dikatakan memiliki kebutuhan khusus jika ada sesuatu yang berbeda dalam dirinya baik berupa keakurangan atau bahkan kelebihan di dalam dirinya dibanding anak pada umumnya. Heward menuturkan (dalam Effendi, 2008:2), bahwa anak dengan kebutuhan khusus adalah anak yang memiliki karakteristik khusus yang tidak sama dengan anak lain pada umumnya baik itu dari segi karakteristik sosialnya, fisiknya maupun mentalnya. Anak-anak dengan kebutuhan khusus ini adalah anak-anak yang membutuhkan penanganan khusus yang berkaitan dengan kelainan dan gangguan perkembangan yang dialami anak tersebut Sementara itu Heri Purwanto, (2007:1), menjelaskan 
bahwa anak-anak dengan kebutuhan khusus adalah anak-anak yang memiliki keunikan tersendiri dalam jenis keunikan dan karakteristiknya, yang membedakan mereka dari anak-anak normal pada umumnya. Keadaan inilah yang menuntut adanya pemahaman terhadap anak-anak dengan kebutuhan khusus. Keragaman anak berkebutuhan khusus yang terjaring oleh sekolah terkadang menyulitkan guru dalam upaya menemukenali jenis kebutuhan dan pemberian jenis layanan pendidikan yang sesuai dengan kebutuhannya.

Kelainan yang dialami anak dengan kebutuhan khusus dalam aspek fisik meliputi kelainan pada indra penglihatan (tunanetra), kelainan pada indra pendengaran (tunarungu), kelainan dalam kemampuan berbicara (tunawicara), dan kelainan pada fungsi anggota tubuh ( tunadaksa). Anak yang memiliki kelainan dalam aspek mental intelektual meliputi anak berkemampuan mental lebih (anak berbakat/gifted), dan anak yang berkemampuan mental rendah (tunagrahita). Sedangkan anak dengan kelainan kemampuan sosial emosionaladalah anak yang memiliki gangguan dalam emosional nya dan memiliki kesulitan dalam mengadaptasikan perilakunya terhadap lingkungan sekitarnya, yang dikenal dengan tunalaras. Dalam pendidikannya, anak-anak tersebut membutuhkan akomodasi seperti metode, material, pelayanan dan peralatan yang khusus yang layak agar dapat mencapai perkembangan yang maksimal dan optimal. Karena anak-anak tersebut mungkin akan belajar dengan kecepatan yang berbeda dan dengan cara yang berbeda. Meskipun mereka memiliki potensi dan kemampuan yang berbeda dengan anak-anak pada umumnya, tetapi mereka tetap harus mendapat perlakuan dan kesempatan yang sama. Hal ini dapat dimulai dengan cara penyebutan terhadap anak dengan kebutuhan khusus.

Menurut Sukmadinata $(2012,24)$, pendidikan berfungsi membantu dan mengembangkan manusia ke arah yang lebih baik atau kepada hal yang positif yang berguna bagi diri dan lingkungannya. Pendidikan bukan hanya memberikan pengetahuan dan melatih keterampilan, namun pendidikan memiliki fungsi mengembangkan apa yang secara potensi dan aktual telah dimiliki peserta didik. Pendidikan menurut Langeveld adalah setiap usaha, pengaruh, perlindungan dan bantuan yang diberikan kepada anak tertuju kepada pendewasaan anakitu, atau lebih tepatnya membantu anak agar cukup cakap melaksanakan tugas hidupnya sendiri. Definisi pendidikan untuk mendewasakan ataupun mengarahkan anak ke hal yang lebih positif, kemudian menurut Soegeng Santoso (2011), perlu ada penambahan unsur pembentukan pribadi yang berkarakter, bermoral, berbudi pekerti dan bertoleransi pada orang lain. Hal tersebut juga sejalan dengan pandangan Ki Hajar Dewantara tentang pendidikan yaitu menuntun segala kekuatan kodrat yang ada pada anak-anak, agar mereka sebagai manusia dan sebagai anggota masyarakat dapatlah mencapai keselamatan dan kebahagiaan setinggi-tingginya. Sementara inklusif adalah sebuah pemikiran tentang kesetaraan dan pelibatan anak secara penuh dan tidak terkotak-kotak pada upaya untuk membuatnya menjadi eksklusif dengan kekhususannya. Secara filosofi Ruth E Cook (2016: 332) 
menyatakan bahwa setting inklusif adalah dimana anak-anak belajar secara alamiah dalam lingkungan dan berinteraksi sesama teman sehingga mereka dapat mengenali persamaan manusia dan secara positif menghargai setiap perbedaan. Secara umum kita memang memahami bahwa setiap individu memiliki keunikan dan perbedaan, sehingga dapat dikatakan bahwa pendidikan dalam setting inklusif adalah sebuah keniscayaan yang menggambarkan hidup bermasyarakat yang beragam. Pendidikan inklusif bukan sekedar metode atau pendekatan pendidikan melainkan suatu bentuk implementasi demokrasi pendidikan yang memandang manusia sebagai makhluk yang memilik hak dan kewajiban yang sama, sehingga dalam mendapatkan pelayanan pendidikan anak-anak dengan kebutuhan khusus harus mendapatkan haknya yang sama seperti anak-anak lainnya. Namun demikian, menurut Margareth Wang (1994/1995), sekolah biasa seharusnya hanya menerima $\mathrm{ABK}$ yang sesuai untuk masuk di sekolah tersebut, bukan menerima semua anak ABK yang berdomisili di wilayah tersebut. Selanjutnya Wang menekankan agar Pendidikan focus pada kekuatan anak tersebut dan bukan pada hal-hal yang menyimpang pada anak.

Beberapa akademisi telah melakukan penelitian terkait anak dengan kebutuhan khusus diantaranya penelitian yang dilakukan oleh Muhdar Mahmud di Bandung tentang layanan dan bimbingan anak dengan kebutuhan khusus tahun 2003. Hasil penelitian Mahmud tersebut menjelaskan bahwa dalam pelayanan dan bimbingan $\mathrm{ABK}$, karena pertimbangan tidak adanya pedoman BP khusus untuk ABK, tidak adanya contoh satuan layanan bimbingan bagi ABK, berkaitan dengan status kepegawaian, dan adanya kecenderungan tentang kekeliruan persepsi konsep bimbingan; menjadi alasan guru untuk tidak membuat satuan layanan dan bimbingan secara khusus. Program yang dibuat guru tersebut meliputi: satuan pelajaran, program caturwulan/semester, program tahunan, program perbaikan, pengayaan, kehadiran, catatan kejadian, kartu komunikasi, kartu pribadi, dan analisis hasil evaluasi pengajaran. Dalam prosesmemahami ABK, guru perlu mengidentifikasi dan mengumpulkan informasi tentang kondisi siswa, latar belakang keluarga, dan kondisi sekolah yang dilakukan melalui angket, wawancara, dan observasi, yang dilakukan sebelum membuat satuan pelajaran dengan tujuan untuk memperoleh gambaran kekuatan, kelemahan, kesulitan dan kebutuhan siswa. Guru mengevaluasi keberhasilan bantuan, menganalisis dan menindaklanjuti hasil penilaian berupa pengayaan dan pengajaran remedial. Masih menurut Mahmud, terdapat enam faktor yang menghambat dalam pelaksanaan bimbingan, yaitu: siswa, orang tua siswa, faktor tenaga bimbingan, personil sekolah, sarana dan prasarana. Dengan demikian, pelaksanaan layanan bimbingan bagi ABK di SD belum optimal. Oleh karena itu, ia merekomendasikan kepada: guru-guru agar terus berusaha mengembangkan kemampuannya melalui pendidikan dan latihan khusus di bidang bimbingan; Kepala Sekolah untuk melakukan pengembangan personil, sarana, dan prasarana bagi pelaksanaan bimbingan; bagi lembaga yang berwenang agar segera mengadakan kegiatan in-service training mengenai bimbingan dan mengoptimalkan mata kuliah BP di LPTK. 


\section{METODE}

Penelitian ini adalah penelitian yang menggunakan pendekatan kualitatif dan menggunakan metode deskriptif. Penelitian deskriptif kualitatif ini bertujuan untuk mendeskripsikan apa adanya tentang kejadian atau fakta, keadaan, fenomena yang terjadi saat penelitian berlangsung dengan menyampaikakan apa yang sebenarnya terjadi di lapangan. Penelitian ini bukan untuk membandingkan variabel pada sampel lain dan bukan juga untuk mencari hubungan satu variabel dengan variabel lainnya. Penelitian kualitatif adalah metode penelitian yang digunakan untuk meneliti pada kondisi objek yang alamiah, dimana peneliti adalah sebagai instrumen kunci, pengambilan sampel sumber data dilakukan secara purposive dan snowball, teknik pengumpulan dengan tringulasi, analisis data bersifat induktif dan hasil penelitiannya lebih menekankan makna dan bukan pada generalisasi (Sugiyono, 2009: 15). Dengan kata lain bahwa penelitian deskriptif kualitatif adalah penelitian yang menggambarkan variabel yang berdiri sendiri, sedangkan data yang diperoleh merupakan kata-kata dan perilaku dari orang-orang yang diamati, baik secara lisan maupun tulisan.

Analisis data dalam penelitian di dua sekolah inklusif di Jakarta Selatan yaitu SDN 01 Lebak Bulus dan SDN 02 Lebak Bulus sebagai sekolah inklusi percontohan, dilakukan sejak sebelum melakukan lapangan dan selama penelitian di lapangan. Data penelitian diperoleh dari hasil wawancara, observasi dan dokumentasi. Teknik analisis data yang digunakan dalam penelitian ini adalah analisis model interaktif yang terdiri dari empat tahapan analisis data. Keempat tahapan itu adalah pengumpulan data, reduksi data, penyajian dan penarikan kesimpulan. Penelitian pengumpulan data di lapangan dengan teknik wawancara, observasi langsung dan dokumentasi.

Data yang didapat di lapangan adalah terkait dengan bagaimana sekolah mengimplentasikan PPI (Program Pendidikan Individual) bagi ABK yang ada di sekolah tersebut. Yang mana data tersebut peneliti bagi menjadi beberapa yaitu:

Ketersediaan payung hukum, perekrutan sumber daya manusia, pembinaan teknis bagi guru tentang program pendidikan individual untuk guru kelas dan guru remedial, realisasi program pendidikan individual dalam pembelajaran yang meliputi perencanaan, pelaksanaan, dan evaluasi, hasil belajar anak dengan kebutuhan khusus, kualitas layanan pendidikan menurut anak berkebutuhan khusus. Setalah wawancara selesai dilakukan maka, peneliti menggunakan teknik dokumentasi dan observasi untuk mendukung hasil wawancara sebelumnya.

Kemudian data yang diperoleh peneliti di lapangan jumlahnya banyak, karna semakin lapa peneliti di lapangan maka akan semakin banyak jumlah data yang diperoleh, semakin kompleks dan rumit, sehingga peneliti harus dapat mencatatnya dengan teliti dan cermat. Oleh karena itu diperlukan analisis data meliputi reduksi data. Reduksi data merupakan proses pemilahan, pemusatan perhatian dan penyederhanan, pengabstrakan, transformasi data kasar yang muncul dari catatan-catatan lapangan (Miles \& Huberman, 16: 1992). Langkah-langkah 
yang dilakukan adalah dengan menajamkan analisis, menggolongkan atau mengategorisasi kedalam setiap permasalahan melalui urian singkat, mengarahkan, mereduksi data yang tidak perlu dan mengorganisasikan data sehingga dapat ditarik kesimpulan dan diverifikasi. Data yang dipilah (direduksi) akan memberikan gambaran yang lebihjelas dan spesifik sehingga memudahkan peneliti dalam melakukan pengumpulan data selanjutnya serta mencari data tambahan jika diperlukan.

Setelah data direduksi, maka langkah selanjutnya adalah penyajian/display data. Penyajian/display data dilakukan untuk mengorganisasikan data agar data tersusun dalam pola hubungan sehingga makin mudah memhaminya. Dalam penelitian kualitatif, penyajian/display data dapat dilakukan dalam bentuk uraian singkat, bagan, hubungan antar kategori, flowchart dan sejenisnya. Namun, dalam menyajikan data kualitatif, teks yang bersifat naratif yang paling sering digunakan (Sugiyono, 338:2009).

Data-data berupa catatan, wawancara, observasi dan dokumentasi diberi kode untuk mengorganisasi data sehingga peneliti dapat dengan mudah dan cepat dalam menganalisis data. Langkah terakhir dalam menganalisa data kualitatif adalah penarikan simpulan. Simpulan kredibel dapat diperoleh apabila simpulan yang dikemukakan pada tahap awal diperkuat dengan bukti-bukti yang valid dan konsisten ketika peneliti kembali ke lapangan menggunakan data. Dengan demikian simpulan dalam penelitian kualitatif dapat saja menjawab atau tidak menjawab perumusan masalah, karena masalah dan perumusan masalah dalam penelitian kualitatif bersifat sementara dan dapat berkembang ketika peneliti berada di lapangan.

Tiga hal yang digunakan dalam analisis data kualitatif yaitu reduksi data, penyajian data dan penarikan simpulan atau verifikasi sebagai sesuatu yang saling berhubungan pada saat sebelum, selama, dan sesudah pengumpulan data (Miles \& Huberman, 20: 1992). Tiga proses tersebut merupakan proses siklus dan interaktif, sehingga peneliti harus siap bergerak di antara empat bagian tersebut selama pengumpulan data, dan kemudian bergerak bolak-balik diantara kegiatan reduksi, penyajian dan penarikan kesimpulan selama sisa waktu penelitian. Aktivitas dalam proses analisis data kualitatif dilakukan secara terus menerus dan interaktif sampai tuntas, sehingga datanya dirasa telah jenuh.

Teknik pengumpulan data merupakan langkah yang paling utama dalam penelitian, karena tujuan dari penelitian adalah mendapatkan data. Pengumpulan data dalam penelitian ini menggunakan wawancara atau interview dan observasi. Selain ini juga digunakan teknik dokumentasi guna memperoleh hasil perolehan data. Peneliti membandingkan informasi yang diperoleh dari satu sumber ke sumber yang lainnya. Hal ini bertujuan untuk mendapatkan jaminan kepercayaan dan menghindari adanya subjektifitas. Data yang diperoleh dari ketiga sumber lalu dideskripsikan, dikategorisasikan mana yang sama, berbeda dan spesifik dari ketiganya. Maka peneliti membandingkan hasil wawancara sumber data satu dengan sumber 
lainnya. Selanjutnya peneliti menarik kesimpulan untuk mencari dan memahami makna dari penelitian yang diperoleh.

\section{PEMBAHASAN HASIL PENELITIAN}

Berdasarkan hasil pengamatan dan wawancara di lapangan diperoleh hasil sebagai berikut:

\begin{tabular}{|c|c|c|}
\hline No & Aspek yang diteliti & Hasil Penelitian \\
\hline 01 & Ketersediaan payung hukum & Tidak ada \\
\hline 02 & Perekrutan sumber daya manusia & Tidak relevan \\
\hline 03 & $\begin{array}{l}\text { Pembinaan dan bimbinganteknis bagi Guru } \\
\text { tentang Program Pendidikan Individual untuk } \\
\text { guru kelas dan guru remedial }\end{array}$ & $\begin{array}{l}\text { Tidak merata dan tidak } \\
\text { berkelanjutan }\end{array}$ \\
\hline 04 & $\begin{array}{l}\text { Realisasi Program Pendidikan Individual } \\
\text { dalam pembelajaran yang meliputi } \\
\text { perencanaan, pelaksanaan, dan evaluasi }\end{array}$ & Tidak terlaksana \\
\hline 05 & Hasil belajar anak berkebutuhan khusus & Rendah Sekali \\
\hline 06 & $\begin{array}{l}\text { Kualitas layanan pendidikan bagi anak } \\
\text { berkebutuhan khusus }\end{array}$ & Tidak sesuai kebutuhan \\
\hline
\end{tabular}

Dari tabel tersebut dapat dijelaskan setiap aspek sebagai berikut:

\section{Ketersediaan Payung Hukum}

Berdasarkan hasil penelitian yang diperoleh melalu wawancara terhadap guru kelas dan kepala sekolah, dijelaskan bahwa payung hukum yang menaungi penyelenggaraan pendidikan inklusi yang pedoman implementasinya dijelaskan dalam PERMENDIKNAS No. 70 Tahun 2009 belum mengatur seluruh aspek yang terkait dengan penyelenggaraan pendidikan inklusi. Pemerintah masih setengah-setengah mengatur kebijakan tersebut. Penyelenggaraan Pendidikan Inklusi di Jakarta sudah menjadi keharusan bagi seluruh sekolah pemerintah yang ada di Jakarta di semua jenjang pendidikan. Hal ini dibuktikan dengan Surat Edaran Pemerintah Provinsi DKI Jakarta melalui Surat Edaran Nomor 119/SE/2016 yang menyatakan bahwa semua satuan pendidikan yang ada di DKI Jakarta harus menjadi sekolah inklusi. Selain itu, pendaftaran peserta didik secara online sangat memungkinkan terjaringnya peserta didik dengan berbagai macam kondisinya. Sehingga dengan dua hal tersebut, otomatis seluruh sekolah terutama sekolah dasar harus menjadi sekolah inklusi. Namun di lain pihak, pemerintah tidak mengatur bagaimana pendidikan inklusi tersebut dapat terselenggara dengan baik. Hal ini dapat dibuktikan dengan tidak adanya nomenklatur yang mengatur tentang hak dan kewajiban guru pembimbing 
khusus yang merupakan salah satu unsur yang vital dalam penyelenggaraan sekolah inklusi. Guru pembimbing khusus seharusnya wajib ada dalam sebuah sekolah inklusi, karena dialah yang akan memberikan pelayanan akademik khusus bagi anak berkebutuhan khusus seperti pelaksanaan program pendidikan yang diindividualkan.

Dalam realisasinya menurut kepala sekolah SDN 02 Lebak Bulus, pengajaran PPI tidak dapat diakui sebagai bagian dari kinerja guru. Karena tidak adanya aturan yang mengatur hakhak dan kewajiban para guru pembimbing khusus tersebut, maka sekolah yang semula merekrut para pendidik dengan latar belakang pendidikan guru luar biasa sebagai guru pembimbing khusus, akhirnya mengalihtugaskan mereka menjadi guru kelas.

\section{Perekrutan Sumber Daya Manusia}

Dalam pedoman implementasi pelaksanaan PPI, perekrutan sumber daya manusia (guru) yang tepat akan menentukan pelaksanaan PPI di sekolah. PPI seharusnya dilaksanakan oleh Guru Pembimbing Khusus (GPK) yang memahami kebutuhan setiap anak berkelainan. Perekrutan Guru Pembimbing Khusus dengan kualifikasi lulusan Program Studi Pendidikan Luar Biasa telah dilakukan oleh sekolah-sekolah yang telah lama menyelenggarakan pendidikan inklusi, tapi tidak dilakukan oleh sekolah-sekolah dasar negeri lainnya. Artinya, berdasarkan hasil wawancara terhadap kepala sekolah SDN 01 Lebak Bulus dan SDN 02 Lebak Bulus menjelaskan bahwa secara sumber daya manusia, untuk SDN 01 Lebak Bulus dan SDN 02 Lebak Bulus telah melakukan perekrutan guru sesuai dengan kebutuhan pendidik dalam penyelenggaraan sekolah inklusi. Namun, karena kebijakan pemerintah yang belum mengatur hak-hak Guru Pembimbing Khusus, akhirnya guru-guru yang semula direkrut dalam rangka pelayanan ABK terpaksa dialihtugaskan menjadi guru kelas. Dan oleh karena tugas utamanya adalah sebagai guru kelas, maka mereka lebih mengutamakan tugas-tugas di kelasnya dari pada melaksanakan PPI untuk seluruh ABK yang terdapat di sekolahnya.

Menurut hasil wawancara terhadap guru kelas 1 SDN 02 Lebak Bulus yang menginisiasi kordinasi Guru Pembimbing Khusus di DKI Jakarta yang berjumlah 200 orang menjelaskan bahwa upaya beberapa elemen yang dihadiri beberapa departemen terkait, eksistensi Guru Pembimbing Khusus telah dan masih diupayakan. Mereka tengah mengusahakan dan mengajukan kurang lebih 200 guru lulusan PLB di Jakarta Selatan untuk dijadikan Guru Pembimbing Khusus yang selama ini menjadi guru kelas. Dengan adanya nomenklatur yang mengatur hak-hak dan kewajiban Guru Pembimbing Khusus diharapkan mereka dapat fokus memberikan pelayanan dan bimbingan kepada anak-anak dengan kebutuhan tanpa dibebani dengan tugas sebagai guru kelas. 


\section{Pembinaan dan BimbinganTeknis bagi Guru Tentang Program Pendidikan Individual untuk Guru Kelas dan Guru Remedial}

Dalam penyelenggaraan pendidikan inklusi, pemahaman dan keterampilan guru tentang bagaimana melayani dan membimbing anak-anak dengan kebutuhan khusus merupakan hal yang sangat penting. Meskipun mereka merupakan lulusan dari Program Studi PLB, tapi penting bagi mereka untuk terus mengupgrade pengetahuan dan mengasah keterampilannya dalam pelayanan dan bimbingan ABK. Apalagi guru-guru kelas yang notabene tidak memahami tentang anak dengan kebutuhan khusus. Namun berdasarkan hasil wawancara terhadap beberapa guru di sekolah SDN 01 Lebak Bulus dan SDN 02 Lebak Bulus yang telah lebih dulu menyelenggarakan pendidikan inklusi sebelum keluarnya edaran Pemerintah Provinsi DKI Jakarta mengatakan terkait dengan wajibnya seluruh sekolah di Jakarta menjadi sekolah inklusi, menjelaskan bahwa pelatihan-pelatihan hanya bersifat insidentil dan tidak berkelanjutan. Itupun hanya menyasar pada guru-guru tertentu saja, sedangkan guru-guru yang lainnya hampir tidak pernah diberikan pelatihan dan bimbingan teknis tentang bagaimana melayani anak-anak dengan kebutuhan tersebut. Sehingga menurut mereka, guru-guru menjadi tidak paham tentang bagaimana melayani anak-anak dengan kebutuhan khusus yang ada di sekolah mereka. Akhirnya anak-anak ABK tidak mendapatkan pelayanan yang seharusnya dan mereka dilayani sama sebagaimana anak-anak normal lainnya.

Berdasarkan hasil wawancara terhadap guru di SDN 02 Lebak Bulus, mereka mengatakan bahwa jika di sekolah yang telah lama menyelenggarakan pendidikan inklusi saja jarang mendapatkan pelatihan-pelatihan dan bimbingan teknis tentang bagaimana melayani anak-anak dengan kebutuhan khusus, apalagi di sekolah-sekolah yang terpaksa menyelenggarakan sekolah inklusi karena adanya surat edaran gubernur. Bukan saja sarana dan prasarana yang sangat tidak memadai, tapi guru-guru yang ada juga tidak memiliki kemampuan sama sekali bagaimana memberikan pelayanan kepada anak-anak dengan kebutuhan khususnya, bahkan mengidentifikasi anak-anak tersebut para guru tidak mengerti. Walhasil, pelayanan untuk anak-anak dengan kebutuhan khusus tidak berbeda dengan pelayanan terhadap anak-anak normal. Bahkan guru cenderung merasa keberadaan anak-anak dengan kebutuhan khusus menjadi beban yang sangat berat bagi mereka.

Oleh karena itu, pemerintah hendaknya memperhatikan secara serius seluruh aspek tentang bagaimana menyelenggarakan pendidikan inklusi. Sehingga diharapkan, penyelenggaraan pendidikan inklusi bukan sekedar pada tataran kebijakan yang implementasinya sama sekali tidak diperhatikan. Konsekuensi dari hal tersebut, hendaknya pemerintah memperhatikan benar seluruh faktor yang terkait dengan penyelenggaraan pendidikan inklusi terutama tentang proses pembelajaran dan pelayanan bagi ABK yang tidak terlepas dari peranan guru-guru yang memahami dan terampil terhadap proses tersebut. Untuk kepentingan tersebut, guru-guru perlu diberikan pelatihan-pelatihan teknis tentang bagaimana mengidentifikasi untuk 
selanjutnya melayani dan membimbing anak-anak dengan kebutuhan khusus yang dilaksanakan secara berkelanjutan, terarah, dan terukur.

\section{Realisasi Program Pendidikan Individual dalam Pembelajaran yang Meliputi Perencanaan, Pelaksanaan, dan Evaluasi}

Tidak jelasnya pemerintah dalam memperhatikan seluruh aspek dalam penyelenggaraan pendidikan inklusi terutama tentang hak-hak dan kewajiban Guru Pembimbing Khusus yang menjadi jantung pelaksanaan proses pembelajaran dan pelayanan bagi anak dengan kebutuhan khusus menyebabkan penyelenggaraan pendidikan inklusi tersebut menjadi banci. Di sekolahsekolah pemerintah, oleh karena belum adanya aturan pemerintah yang melindungi hak-hak Guru Pembimbing Khusus memaksa sekolah yang telah merekrut guru dengan latar pendidikan dari Program Studi Pendidikan Luar Biasa terpaksa mengalihkan tugas mereka sebagai guru pembimbing khusus menjadi guru kelas. Sementara di sekolah inklusi swasta, keberadaan guru pembimbing khusus masih belum diberikan hak yang sesuai. Sehingga sekolah swasta terpaksa merekrut guru-guru ini tanpa memperhatikan latar belakang pendidikannya (Masyithoh: 2012). Demikian juga yang terjadi di sekolah-sekolah pemerintah yang terpaksa menjadi sekolah inklusi karena edaran gubernur. Menurut hasil wawancara terhadap guru di SDN 02 Lebak Bulus bahwa sekolah harus menerima guru dengan latar pendidikan dari sekolah vokasional karena pengangkatan guru CPNS dari jalur honorer. Kondisi di atas semakin mempersulit implementasi Program Pendidikan Individual bagi anak-anak berkebutuhan khusus di sekolah-sekolah tersebut.

Berdasarkan hasil wawancara terhadap guru yang awalnya direkrut untuk menjadi guru pembimbing khusus dengan latar belakang pendidikan yang sesuai, mereka sangat memahami bagaimana memberikan pelayanan anak berkebutuhan khusus termasuk bagaimana membuat Program Pendidikan Individual bagi anak-anak tersebut. Namun karena dialihkan menjadi guru kelas dan beratnya beban menjadi guru kelas, membuat mereka terpaksa tidak lagi melaksanakan Program Pendidikan Individual bagi seluruh anak-anak berkebutuhan khusus yang terdapat di sekolah mereka. Beliau hanya memberikan Program Pendidikan Individual pada anak-anak dengan kebutuhan tertentu yang benar-benar membutuhkan yang ada di kelasnya. Itupun sifatnya tidak berkelanjutan.

Menurut beliau, dari 80 orang guru yang tergabung dalam suatu WA Grup, dimana mereka awalnya direkrut sebagai Guru Pembimbing Khusus yang kemudian dialihkan menjadi guru kelas, sekitar $95 \%$ dengan terpaksa tidak pernah melaksanakan Program Pendidikan Individual bagi anak-anak berkebutuhan khusus yang terdapat di sekolah mereka. Beberapa 
diantaranya kadang-kadang masih memberikan pelayanan individual dan berkoordinasi dengan orang tua anak-anak tersebut meski sifatnya tidak berkelanjutan. Sementara di sekolah-sekolah lainnya, seluruh guru yang terdapat di sekolah-sekolah tersebut dapat disimpulkan tidak melaksanakan Program Pendidikan Individual karena mereka tidak memiliki pemahaman dan kemampuan mengidentifikasi dan melayani anak-anak berkebutuhan khusus tersebut.

Lebih lanjut beliau menjelaskan bahwa meratanya ketidakpahaman guru dalam mengidentifikasi dan melayani ABK, seringkali mengalami kesulitan dalam menjalankan program yang dirancang bagi anak berkebutuhan tersebut yang membutuhkan kerja sama dengan guru-guru yang lainnya. Sehingga program-program yang direncanakan menjadi gagal terlaksana.

Berdasarkan hasil penelitian ini maka realisasi pelayanan program pendidikan individual pasti tidak akan terlaksana jika tidak ada sumber daya yang menjalankannya. Kalaupun sumber daya manusia tersedia, maka dalam suatu negara hukum, mereka tidak akan berfungsi tanpa payung hukum yang mengatur hak-hak dan kewajiban mereka. Hal ini perlu diperhatikan oleh pemerintah terkait. Karena di proses pelayanan inilah yang akan menentukan berhasil tidaknya penyelenggaraan pendidikan inklusi.

Memahami hal tersebut di atas, perlu kiranya pemerintah segera mengeluarkan segala kebijakan yang terkait dengan penyelenggaraan pendidikan inklusi termasuk hak-hak dan kewajiban guru pembimbing khusus, sarana dan prasana dan seluruh aspek yang terkait dengan penyelenggaraan sekolah inklusi secara komprehensif.

\section{Hasil Belajar Anak Berkebutuhan Khusus}

Dampak dari realisasi program pendidikan individual adalah prestasi belajar anak-anak dengan kebutuhan khusus. Dengan memberikan pelayanan yang maksimal kepada anak-anak tersebut, diharapkan dapat mengoptimalkan potensi yang mereka miliki. Bagi anak-anak tunagrahita misalnya, prestasi yang dimaksud tidak harus berupa prestasi akademik yang cemerlang karena memang kondisi internal dirinya yang tidak memungkinkan. Tujuan pelaksanaan program pendidikan individual adalah agar anak-anak dengan kebutuhan ini mendapatkan pelayanan sesuai dengan kondisinya dengan menghasilkan optimalisasi potensi yang merek miliki agar menjadi manusia yang mandiri dan atau berprestasi.

Sejauh ini, prestasi anak-anak dengan kebutuhan khusus tergantung pada kebutuhan yang dimilikinya. Jika anak tersebut memiliki kebutuhan di aspek intelektual, maka dengan tidak terealisasinya Program Pendidikan Individual sangat berpengaruh pada hasil yang diperoleh. Rata-rata mereka menjadi paling terbelakang dari sisi akademik dibandingkan teman-teman yang lainnya. Sehingga jika memang sangat tidak memungkinkan bagi anak untuk mengikuti ujian 
nasional, guru membuat pernyataan yang ditandatangani sekolah dan orang tua yang menjelaskan bahwa anak yang bersangkutan tidak dapat mengikuti ujian nasional.

Jika program pendidikan yang diindividualkan terlaksana dengan baik, maka idealnya prestasi akademik anak-anak normal dengan anak-anak dengan kebutuhan tidaklah jauh berbeda. Kecuali jika kebutuhan mereka di aspek intelektual/tunagrahita. Anak-anak seperti mereka tentu perlu diberikan layanan pendidikan yang menstimulus kemandirian mereka. Program-program tersebut dapat berupa pendidikan yang diindividualkan, atau dapat pula berupa bina diri. Anak dengan kebutuhan ini dapat diajukan untuk tidak diikutkan pada event ujian nasional dan selanjutnya diarahkan pada pendidikan vokasional yang sesuai dengan potensi yang mereka miliki. Sedangkan untuk anak-anak selain tunagrahita, karena mereka relatif tidak bermasalah pada kemampuan intelektual mereka, untuk mencapai tujuan yang ditetapkan, hendaklah pemerintah, sekolah, dan guru dapat menyediakan akomodasi yang layak bagi mereka sesuai dengan kebutuhannya sehingga potensi mereka dapat berkembang secara optimal.

\section{Kualitas Layanan Pendidikan Menurut Anak Berkebutuhan Khusus}

Salah satu aspek yang perlu digali adalah tentang persepsi siswa dengan kebutuhan khusus terhadap layanan sekolah. Apakah sekolah telah memberikan layanan kepada mereka dengan baik atau tidak. Apakah mereka merasa nyaman bersekolah bersama-sama dengan anakanak atau tidak.

Berdasarkan hasil wawancara terhadap beberapa anak berkebutuhan khusus yang terdapat di SDN 02 Lebak Bulus mengatakan bahwa dia merasa senang dan asyik di sekolah tersebut. Hal ini karena guru yang menjadi guru kelasnya berlatar belakang pendidikan PLB. Meskipun tidak maksimal, guru yang bersangkutan telah berusaha memberikan pelayanan khusus yang terindividualisasi bagi mereka. Akan tetapi bagi anak ABK di kelas yang gurunya tidak berlatar belakang pendidikan PLB, maka mereka diperlakukan sama sebagaimana anakanak lainnya dan sama sekali tidak mendapatkan Program Pendidikan Individual.

Di banyak sekolah negeri yang dipaksa menjadi sekolah inklusi, sama sekali belum menyiapkan segala perangkat yang seharusnya dimiliki oleh sebuah sekolah dengan setting inklusi. Berdasarkan hasil wawancara, guru-guru bahkan tidak mengerti sama sekali tentang anak-anak tersebut. Tidak mengerti bagaimana mengidentifikasi apalagi melayani mereka. Hal ini terjadi bukan saja karena tidak adanya guru pembimbing khusus atau guru yang berlatar belakang pendidikan PLB, akan tetapi juga karena pemerintah dan sekolah tidak memberikan atau memfasilitasi mereka untuk mengikuti pelatihan-pelatihan maupun bimbingan teknis tentang bagaimana memberikan pelayanan bagi anak-anak berkebutuhan khusus tersebut. Para guru tersebut hanya tahu bahwa ada anak-anak yang berbeda dari anak pada umumnya di kelas 
mereka, akan tetapi bagaimana mengidentifikasi dan bagaimana melayaninya, mereka tidak paham sama sekali.

\section{SIMPULAN}

Pendidikan Inklusif adalah kebersamaan untuk memperoleh pelayanan pendidikan dalam satu kelompok secara utuh bagi seluruh anak dengan kebutuhan khusus usia sekolah, agar anak dengan kebutuhan khusus dapat bersosialisasi dan berintegrasi dengan anak sebayanya di sekolah regular, juga merupakan solusi terhadap kendala sulitnya anak dengan kebutuhan khusus untuk mendapatkan pelayanan pendidikan secara utuh terutama di desa dan daerah terpencil. Dan, untuk tercapainya tujuan yang ditetapkan, diperlukan kurikulum khusus dan lentur yang gunakan bagi anak dengan kebutuhan khusus, kurikulum tersebut harus bersifat fleksibel sesuai dengan kemampuan atau kebutuhan peserta didik, diantaranya adalah program pembelajaran individual (Individualized Education Program/IEP). Program pembelajaran individual merupakan suatu kurikulum terindividualisasi yang didasarkan kepada kebutuhan khusus anak dalam belajar, karena dalam sekolah dengan pendekatan pendidikan inklusif tersebut terdapat anak dengan kebutuhan yang memiliki karakteristik, kebutuhan dan kemampuan yang berbeda, juga perlu diperhatikan bagaimana proses pembelajaran individual dapat dilaksanakan dengan baik tanpa harus merusak keberadaan kurikulum yang ada, dengan menyelaraskan kesenjangan antara kondisi yang ada dengan kondisi yang diharapkan Undang-undang No 20, tentang Sistem Pendidikan Nasional, Tahun 2003.

Implementasi Program Pembelajaran Individual (PPI) di lapangan ternyata masih jauh panggang dari api. Hampir 95\% guru tidak melaksanakan PPI. Hal ini diakibatkan karena beratnya beban sebagai guru kelas, sehingga tidak sempat bagi mereka untuk merumuskan konsep PPI. Hal ini terjadi karena belum adanya nomenklatur yang mengatur tentang hak-hak dan kewajiban guru pembimbing khusus. Tidak hanya itu, pemerintah juga seakan-akan tidak serius dalam penyelenggaraan sekolah/pendidikan untuk semua anak tanpa terkecuali. Semua usaha dan pengajaran yang dilakukan guru pembimbing khusus tidak diatur oleh Undangundang dan tidak diakui sebagai jam mengajar. Kondisi ini memaksa kepala sekolah untuk mengalihkan tugas Guru Pembimbing Khusus yang seharusnya bertanggung jawab dalam pelaksanaan PPI, menjadi guru kelas. Akibatnya guru yang semula direkrut sebagai guru pembimbing khusus yang bertanggung jawab terhadap pelayanan khusus bagi anak dengan kebutuhan khusus menjadi tidak melaksanakan apa yang seharusnya dilaksanakan oleh guru pembimbing khusus dalam suatu sekolah setting inklusif. Oleh sebab itu, maka PPI sebagai salah satu bentuk pelayanan yang seharusnya diberikan kepada anak-anak dengan kebutuhan di sekolah inklusi tidak terimplementasi. 


\section{Implikasi}

Berdasarkan temuan hasil penelitian yang telah dibahas sebelumnya maka ada beberapa hal yang menjadi implikasi dari penelitian ini diantaranya:

1. Pemerintah seharusnya mulai menyadari bahwa kebijakan tentang penyelenggaraan pendidikan inklusi belum komprehensif.

2. Diperlukan kajian secara matang dan mendalam sebelum sebuah kebijakan digulirkan.

3. Kebijakan penyelenggaraan pendidikan inklusi hendaknya dibarengi dengan kebijakankebijakan lain yang menjadi bagian terpenting dalam penyelenggaraannya.

4. Pihak-pihak terkait menyadari bahwa layanan pendidikan terindividualisasi bagi anak dengan kebutuhan khusus belum terimplementasi.

5. Perlu adanya dorongan dan usaha secara sinergis antara berbagai elemen terkait kepada pemangku kebijakan untuk segera menggulirkan aturan-aturan yang berhubungan dengan hak-hak dan kewajiban guru pembimbing khusus agar pelayanan terindividualisasi bagi anak dengan kebutuhan khusus dapat terlaksana sesuai aturan yang diberlakukan.

6. Diperlukan sumber daya manusia yang mumpuni untuk melayani pendidikan anak dengan kebutuhan khusus di sekolah inklusi.

7. Dilaksanakannya pelatihan-pelatihan dan bimbingan teknis yang berkesinambungan dan terarah untuk seluruh guru-guru di sekolah-sekolah inklusi

\section{DAFTAR PUSTAKA}

Abdurrahman, Mulyono, Pendidikan bagi Anak Berkesulitan Belajar, Jakarta: Rineka Cipta, 2003.

Assjari, Musjafak, Program Pembelajaran Individual, Departemen Pendidikan Nasional Direktorat Jenderal Manajemen Pendidikan Dasar dan Menengah Direktorat Pembinaan Sekolah Luar Biasa, 2005.

Baker, Edward T., Margareth C. Wang and Herbert J. Walberg, "Synthesis of Research: The Effect of Inclussion on Learning”. Educational Leadership, 52, pp 33-35. 1994/1995.

Cook, Ruth. E.; Klein, M. Diane; Chen, Deborah, Adapting Early Childhood Curricula for Children with Special Needs, Boston: Pearson, 2016.

Effendi, Muhammad, Pengantar Psikopedagogik Anak Berkelainan, Jakarta: Remaja Rosdakarta, 2008.

Kitano, M.K.; \& Kirby, D. F., Gifted Education, Boston: Little Brown and Company, 1986.

Lerner, Janet W., Learning Disabilities: Theories, Diagnosies, and Teaching Strategies, New Jersey: Houghton Mifflin Company, 1988.

Masyithoh, Siti, Laporan Penelitian Kompetensi Guru Pembimbing Khusus, Jakarta: UMJ, 2012.

Miles \& Huberman, Analisis Data Kualitatif, Jakarta: UI Press, 1992. 
Siti Masyithoh

PERMENDIKNAS No. 70 Tahun 2009 tentang pendidikan inklusif

Pemerintah Provinsi DKI Jakarta, Surat Edaran surat edaran Nomor 119/SE/2016 tentang Penyelenggaraan Sekolab Inklusi, Jakarta: 2016.

Santoso, Soegeng, Konsep Pendidikan Anak Usia Dini Menurut Pendirinya 1, Jakarta: UNJ, 2011.

Sugiyono, Metode Penelitian Pendidikan: Pendekatan Kuantitatif, Kualitatif Dan R\&D, Bandung: CV. Alfabeta, 2009.

Sukmadinata, Nana Syaodih, Metode Penelitian Pendidikan, Bandung: PT. Remaja Rosdakarya, 2012.

Suparno, Heri Purwanto, Edi Purwanto, 2007. Modul Pendidikan Anak Dengan kebutuhan Khusus, Jakarta: PJJ PGSD.

, Pendidikan Anak Berkebutuban Khusus, Jakarta: Direktorat Jenderal Pendidikan Tinggi Departemen Pendidikan Nasional, 2007.

Vina. R. A. \& Thousand, J. S. (Eds). Creating In Inclusive School, Alexandria: Association for Supervision and Curricullum Development (ASCD). 1995.

Wirawan, Evaluasi: Teori, Model, Standar, Aplikasi, dan Profesi, Depok: PT. Rajagrafindo Persada, 2012. 